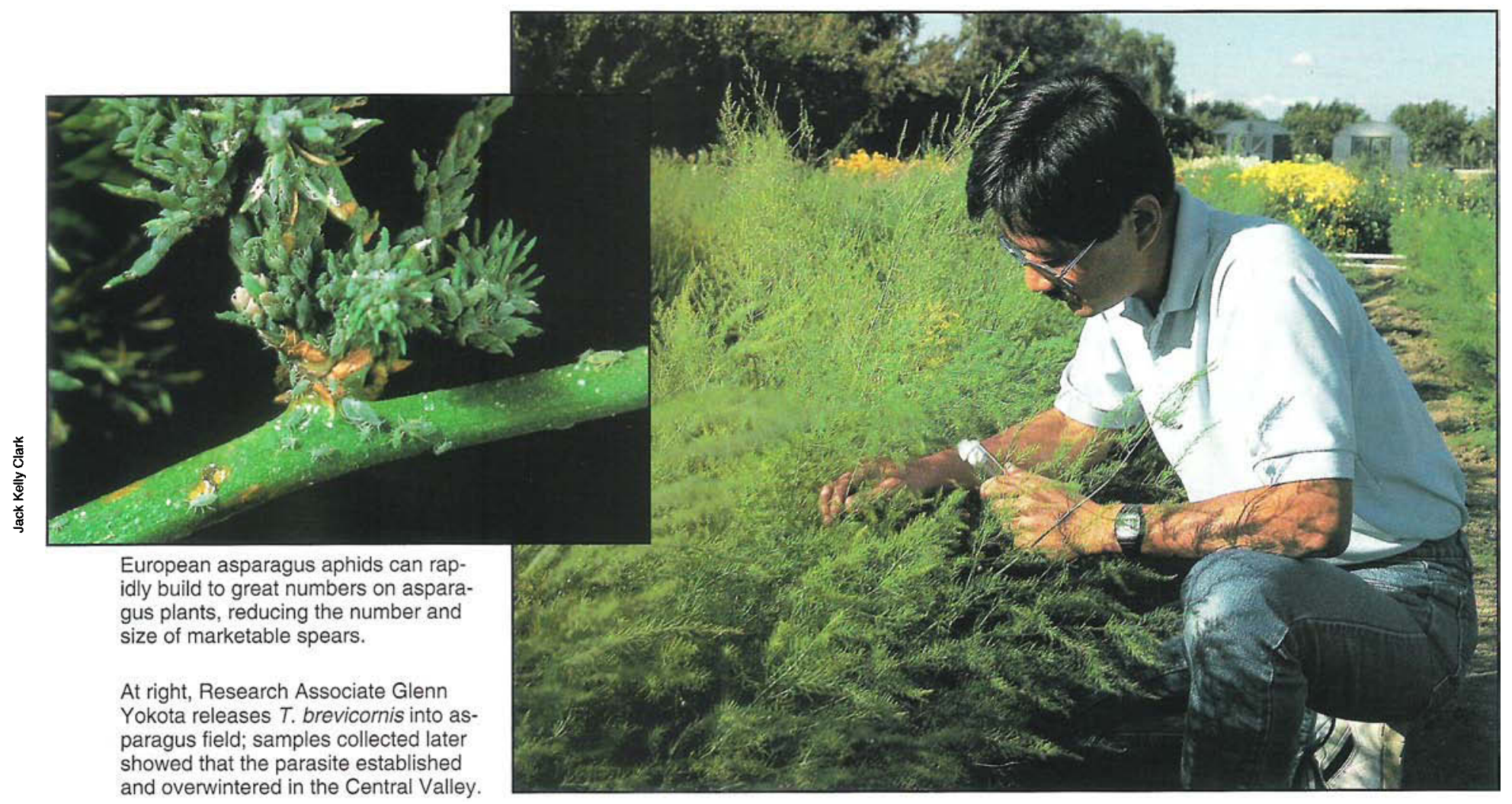

\title{
Imported parasite may help control European asparagus aphid
}

\author{
Kent M. Daane $\square$ Glenn Y. Yokota $\square$ Richard F. Gill $\square$ Leopoldo E. Caltagirone $\square$ Kenneth S. Hagen \\ Dan Gonzalez \ Petr Stary $\square$ William E. Chaney
}

The parasite Trioxys brevicornis was imported from Czechoslovakia and released in California to help control the European asparagus aphid. Field performance of this parasitic wasp indicates it has potential to become permanently established in California. Aphid parasitism by $\mathrm{T}$. brevicornis was especially good in comparison.
Garden asparagus, Asparagus officinalis, is a perennial crop ranking tenth among vegetables produced in California, and was relatively free of major pests until the European asparagus aphid (EAA), Brachycorynella asparagi, was first found in the Coachella Valley in 1984. Since then, the pest has extended to most of the state's asparagus-producing areas, and growers have employed chemical and cultural controls to avoid the sort of substantial economic losses that occurred when EAA was first reported in the western United States in 1979, in Washington. EAA's spread in California and its damage to the asparagus plant have been described before in California Agriculture (September-October 1987).

Natural enemies had reportedly provided sufficient control in asparagus fields in the eastern United States, but control had been inadequate or sporadic in the western states. The possibility of improving biological control has long been recog- nized because in Europe, where EAA is widespread, its natural enemies seldom allow it to reach pest status.

To detect a natural enemy that could be effective in California, we reared five species of EAA natural enemies at the UC Quarantine Facility, Division of Biological Control, Albany, from material collected in Czechoslovakia, Hungary, and Switzerland. Among them was Trioxys brevicornis. We report here on efforts to establish this parasite in California.

\section{EAA's life cycle}

EAA is a small (1/16 inch), blue-green to gray aphid, covered with a powdery coating. The EAA life cycle is complex. In temperate climates, the small, black EAA eggs overwinter on old ferns and in the soil. Eggs hatch in spring and produce wingless adults. These in turn produce several asexual generations during summer, and aphid populations rapidly increase to large numbers. Winged forms also can de- 


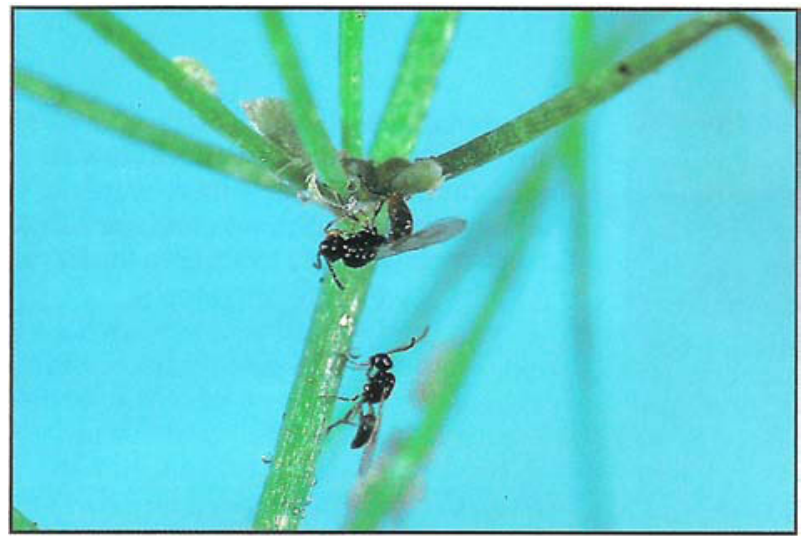

Above, Trioxys brevicornis on asparagus oviposits into EAA as second $T$. brevicornis searches for EAA. At right, EAA mummies have been parasitized by T. brevicornis.

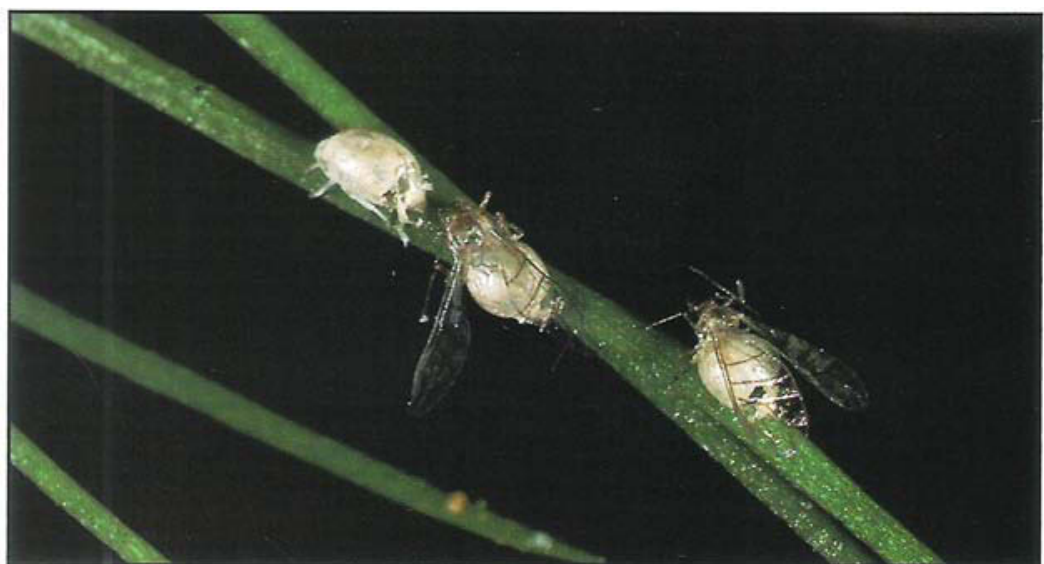

velop at this time in response to environmental factors, such as crowding, and can fly to uninfested asparagus. In fall, sexual females and winged males are produced, mate, and lay eggs on the fern to begin the overwintering cycle. In warmer climates, EAA asexual generations continue uninterrupted.

Infested plants have a tufted appearance marked by a blue-gray-green color. EAA infestations can cause localized stunted growth and may cause plants to become more susceptible to fusarium wilt. The aphid injects a toxin that apparently interferes with nutrient storage in the roots. After serious infestations, the following season's asparagus crop can be reduced in number and size of marketable spears.

Control practices include sanitation and application of Malathion and Disyston, the insecticides registered for use against EAA in California. Both chemicals are applied after harvest at the plant's fern stage. Sanitation consists of cutting and burning ferns between November and January after fern die-back.

Several EAA natural enemies were present in California before 1989, including general predators (lady beetles, green and brown lacewings, syrphid flies) and aphid parasites (Diaeretiella rapae, Aphelinus sp., and Aphidius colemani).

\section{Parasite release}

The most common parasite reared out of Czechoslovakian shipments of EAA was T. brevicornis. This braconid wasp had never been reported released in North America.

Release sites with sufficient populations of EAA and no pesticide treatments were chosen in Contra Costa, Monterey, San Joaquin, Fresno, and Tulare counties. Insectary-reared parasites were collected, and between 100 and 200 T. brevicornis were released at the base of asparagus plants with dense populations of EAA in each release site. In 1989, parasite releases began in September and ended in Decem- ber, when EAA population density declined. In 1990, parasite releases began in June and ended in November. In total, 14,090 and 54,065 T. brevicornis were released in 1989 and 1990, respectively; most were distributed in Fresno and Tulare counties (table 1).

Research plots in Contra Costa, Monterey, and San Joaquin counties were sampled once before and once after the $T$. brevicornis release. Parasitized aphids that were found were taken to the laboratory for parasite emergence and identification.

Release sites in Fresno and Tulare counties were sampled every 2 weeks before parasite release and weekly (1989) or every 2 weeks (1990) thereafter, until plant die-back and removal in December. Plants

\begin{tabular}{|c|c|c|c|c|}
\hline \multirow[b]{2}{*}{ County } & \multirow[b]{2}{*}{ Month } & \multirow[b]{2}{*}{ Location } & \multicolumn{2}{|c|}{ Number } \\
\hline & & & $1989^{\star}$ & $1990^{*}$ \\
\hline Contra Costa & $\begin{array}{l}\text { August } \\
\text { September }\end{array}$ & $\begin{array}{l}\text { Brentwood } \\
\text { Lathrop }\end{array}$ & $\begin{array}{l}115 \\
550\end{array}$ & - \\
\hline San Joaquin & $\begin{array}{l}\text { August } \\
\text { September }\end{array}$ & $\begin{array}{l}\text { Stockton } \\
\text { Stockton }\end{array}$ & - & $\begin{array}{r}5,000 \\
550\end{array}$ \\
\hline Monterey & October & Soledad & 200 & - \\
\hline Fresno & $\begin{array}{l}\text { June } \\
\text { July } \\
\text { August } \\
\text { September } \\
\text { October } \\
\text { November } \\
\text { December }\end{array}$ & $\begin{array}{l}\text { Fowler } \\
\text { Fresno/Fowler } \\
\text { Fresno/Fowler } \\
\text { Fresno } \\
\text { Fresno/Fowler } \\
\text { Fresno/Fowler } \\
\text { Fowler }\end{array}$ & $\begin{array}{r}- \\
- \\
410 \\
5,270 \\
2,900 \\
1,100\end{array}$ & $\begin{array}{r}6,300 \\
2,815 \\
1,650 \\
7,350 \\
7,250 \\
- \\
-\end{array}$ \\
\hline Tulare & $\begin{array}{l}\text { August } \\
\text { September } \\
\text { October } \\
\text { November }\end{array}$ & $\begin{array}{l}\text { Visalia } \\
\text { Visalia } \\
\text { Visalia } \\
\text { Visalia }\end{array}$ & $\begin{array}{r}- \\
325 \\
475 \\
1,745\end{array}$ & $\begin{array}{l}1,700 \\
5,700 \\
3,300 \\
2,450\end{array}$ \\
\hline Total & & & 14,090 & 54,065 \\
\hline
\end{tabular}

*Dash line represents sampling dates on which no samples were taken at a particular site.

TABLE 2. Common primary and secondary parasites reared from asparagus aphid samples collected at four Trioxys brevicornis release sites in Fresno and Tulare counties, 1989 and 1990, showing relative abundance

\begin{tabular}{lll}
\hline \hline EAA & \multicolumn{2}{c}{ Individuals collected } \\
\cline { 2 - 3 } $\begin{array}{l}\text { parasite } \\
\text { species }\end{array}$ & Capsule $\quad$ Container & Capsule Container \\
\hline
\end{tabular}

Primary parasites

$\begin{array}{lllll}\text { Trioxys brevicornis } & 2 & 58 & 77 & 219\end{array}$

Diaeretiella rapar

Pachyneuron siphonophorae

Syrphophagus aphidivorus

Aphelinus sp. (near semiflavus)

Secondary parasites

Asaphes sp.

Alloxysta sp.

$\begin{array}{rrrr}2 & 58 & 77 & 219 \\ 6 & 65 & 21 & 33 \\ 17 & 110 & 13 & 54 \\ 9 & 85 & 4 & 86 \\ 24 & 379 & 14 & 290 \\ & & & \\ 5 & 15 & 6 & 2 \\ 6 & 23 & 4 & 22\end{array}$

*Parasites reared from mummies isolated individually in capsules are distinguished from those placed collectively in emergence containers because of hyperparasite activity. Actual percent parasitism was below $5 \%$ (see fig. 1). 
were sampled randomly in each field; secondary branches were examined for presence or absence of aphids until 15 infested branches were found or 30 branches were collected. Infested branches were taken to the laboratory, where branch length, numbers of EAA, and numbers of mummies were recorded.

Parasitized EAA were isolated in gelatin capsules for rearing of primary and secondary parasites. Mass collections of EAA were also made at each release site, and this field material was taken to the laboratory and similarly examined for parasites. Parasites were identified and their numbers recorded.

\section{Overwintering potentlal}

In December, EAA nymphal and adult population densities drop sharply as asparagus ferns enter dormancy. Normal sanitation practices (cutting and burning the tops of asparagus ferns) remove many overwintering EAA. The following year's crop is most likely reinfested from EAA colonies on wild asparagus plants or from EAA eggs remaining in the soil. Trioxys brevicornis overwinter mainly in mummified EAA on the ferns, so sanitation practices also reduce parasite numbers. Because the overwintering potential of the parasite is important for its success, that potential was observed in field studies.

In the four Fresno and Tulare county release sites, grower collaborators left some asparagus plants standing throughout the winter or, after cutting ferns back in December, placed the cut material at the outskirts of the field. Samples from the cut material were taken in December 1989 and January 1990 and brought to the laboratory and examined for EAA. Mummies were placed in gelatin capsules and held for parasite emergence. The remaining material was placed outside in organdycovered sleeve cages that were examined every other week for EAA mummies or emerged parasites, from December 1989 to April 1990.

\section{Results}

In Fresno and Tulare counties, T. brevicornis was recovered at each site in 1989 and 1990. Table 2 shows the numbers of $T$. brevicornis and common primary and secondary parasites reared from EAA. Trioxys brevicornis performance looked especially good in comparison with the well-established $D$. rapae. There was a more noticeable difference between these two parasites in 1990 than in 1989. Release and recovery efforts in 1989 were hampered by the late-season arrival of T. brevicornis from Europe. EAA numbers were already declining in some fields by the time parasite material was available from the insec- tary. Also, the number of secondary parasites was high at the end of the season and this may have interfered with the 1989 release. However, recovery of $T$. brevicornis was similar to that of $D$. rapae in number and time sequence. In 1990, with earlier release dates and larger release numbers, $T$. brevicornis was recovered at numbers approximately five times greater than $D$. rapae in our release sites.

Figure 1 shows the population dynamics of EAA and its primary parasites at two of the four Central Valley release plots (all four plots had similar EAA and parasite patterns). Soon after EAA entered the field, aphid density markedly increased, peaking between July and August, then rapidly declining, and peaking again between September and October. The increase in aphid density seen in both graphs on the final collection date is due to the die-back or cutting of the taller ferns, which caused the remaining aphids to accumulate on the sampled secondary or tertiary branches that remained green late into the season.

From the asparagus plant material left in each field, we collected T. brevicornis, as well as $D$. rapae and Aphelinus sp., and the secondary parasites Alloxysta sp. and Asaphes sp., in February, March, and April of 1989 and 1990. By the end of April, the plant material set aside was old, and new fern growth was beginning in the field. Field sampling was then resumed and both $T$. brevicornis and $D$. rapae were
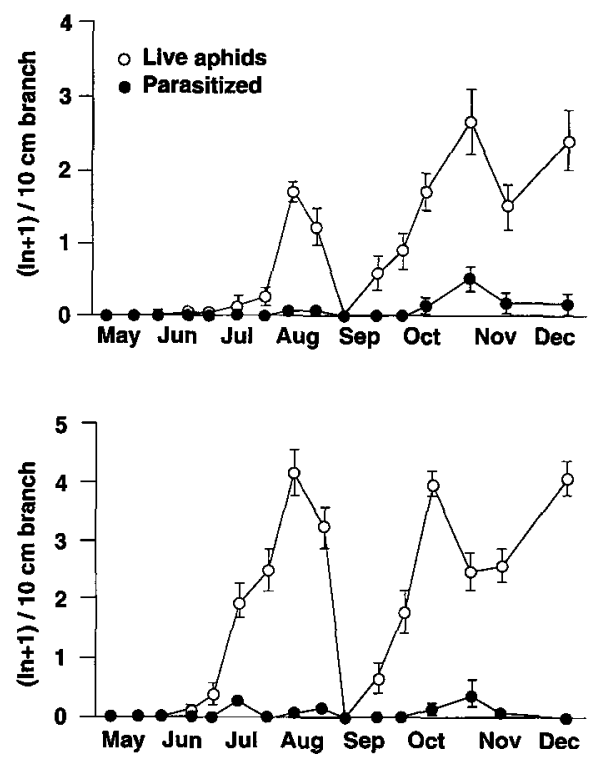

Fig. 1. Population dynamics of the European asparagus aphid and its primary parasites in two asparagus fields where released Trioxys brevicornis had been recovered in 1990.

Maitre farm (top) and California State Univer. sity (bottom) asparagus fields are located in Fresno. reared from collected EAA mummies in similar numbers. Because there were no releases during winter, we concluded that $T$. brevicornis was able to survive the Central Valley's winter temperatures.

No recoveries were made in Contra Costa, Monterey, or San Joaquin counties in 1989 or 1990; however, this may not be a fair assessment of the potential usefulness of T. brevicornis in those regions. In 1989, parasite releases were made late in the season as aphid density was sharply declining. It is probable that neither sufficient time nor sufficient host material were present for T. brevicornis to increase in sufficient numbers for detection in our samples. The release site selected in 1990 was destroyed by an inadvertent insecticide treatment only a few weeks after parasite release.

\section{Conclusions}

Trioxys brevicornis was not released in fields after November 1990 because that would have made it difficult to determine whether the parasite were already becoming permanently established in Fresno and Tulare counties, where the parasites had been recovered. Collections of EAA mummies were resumed in August 1991 in two of the four release fields, and T. brevicornis was again recovered. We believe that the survival of this parasite during the freeze of 1991 and the following summer, without additional releases, indicates its ability to withstand California's environmental conditions.

Overall, primary parasite activity never accounted for more than $10 \%$ parasitism of collected EAA on any one collection date; the effect of parasites on EAA population dynamics, however, cannot be determined from these data. We hope to continue releases in coastal and Delta locations to establish this parasite and to document its enhancement of the natural enemy complex of the European asparagus aphid.

K. M. Daane is Assistant Specialist and G. Y. Yokota and R. F. Gill are Research Associates, Division of Biological Control at Kearney Agricultural Center; L. E. Caltagirone and K.S. Hagen are Professor and Professor Emeritus, Division of Biological Control, UC Berkeley; D. Gonzalez is Entomologist, UC Riverside; $P$. Stary is Entomologist, Czechoslovakia Academy of Sciences; and W. E. Chaney is Farm Advisor, Monterey County.

The authors thank Dennis Meals and John Andrews, Division of Biological Control, UC Berkeley; Bill Rousch, California State University, Fresno; and the California State University, Fresno, and the Knoll, Lovett, Maitre, $\mathrm{McNabb}$, Vera, and Wysinger farms for use of their asparagus fields. 